\title{
Diurnal cycle of rainfall and surface winds and the mid-summer drought of Mexico/Central America
}

\author{
Scott Curtis* \\ Department of Geography, East Carolina University, 227-A Brewster Building, Greenville, North Carolina 27858, USA
}

\begin{abstract}
This study uses a novel data set of satellite-derived precipitation and reanalysis winds to describe variations in the diurnal cycle during the summer season in southern Mexico, Central America, and adjacent oceans, with the purpose of elucidating local forcing mechanisms of the midsummer drought (MSD). It is well established that precipitation peaks in the evening over land, while just off the Pacific coast the maximum is during the day. However, little is understood about the diurnal cycle of rainfall and winds associated with the MSD, a climatological phenomenon that impacts the local population. First, the MSD was quantified with the precipitation data and found to be strongest over Guatemala and El Salvador, consistent with previous studies. Over Guatemala the strength of the diurnal cycle follows the evolution of the MSD. Here evening precipitation rates are $25 \%$ higher at the beginning and end of the summer compared to mid-summer, while daytime rates remain fairly constant throughout the season. To the south, over the Pacific, both daytime and nighttime precipitation rates are higher at the beginning and end of summer as compared to mid-summer. In June, surface winds in the vicinity of the Gulf of Tehuantepec are southerly during the evening and northerly during the day, dynamically consistent with the diurnal cycle of convection. In July-August and September, tradewind systems disturb this apparent local circulation cell bringing conditions conducive to reduced and enhanced rainfall respectively. In neighboring areas where the MSD is weak, precipitation and wind change little over land and ocean for the summer season. Thus, these results support earlier studies linking solar forcing of sea surface temperatures and changes in the large-scale circulation in the development of a strong but localized MSD.
\end{abstract}

KEY WORDS: Mid-summer drought $\cdot$ Rainfall $\cdot$ Diurnal cycle $\cdot$ Satellite $\cdot$ Mexico $\cdot$ Central America Resale or republication not permitted without written consent of the publisher

\section{INTRODUCTION}

Southern Mexico and Central America, situated between the Pacific Ocean and the Gulf of Mexico/ Caribbean, have a varied topography including mountain chains such as the Sierra Madre and Cordillera de Talamanca. The Pacific coast is a mix of tropical deciduous forest, savanna, and agriculture, with beaches that attract many tourists (Arbingast 1975, Diagram Group 1985). This region is also home to a climatological phenomenon unique to the western hemispherethe mid-summer drought (MSD), where precipitation during the rainy season decreases by roughly $40 \%$ in late July and early August, compared to June and September (Hastenrath 1967). Thus, the MSD can be characterized as a bimodal distribution of summertime rainfall. Curtis (2002) used the variance explained by the second order harmonic of a fourier transform of climatological May to October precipitation globally to determine the relative strength of the MSD. He found, quantitatively, that summer rains in the region of Central America were more strongly bimodal than any other region in the world.

Magaña et al. (1999) (hereafter MAM99) was one of the first studies to try to explain this temporal characteristic of precipitation. They proposed 3 mechanisms for the MSD that occur primarily over the eastern Pacific: (1) a decrease in solar radiation from enhanced cloudiness and rainfall; (2) divergent wind anomalies caused by an anticyclonic circulation of low level winds and strengthening of the tradewinds; and (3) an increase in evaporation from wind stirring (see 
MAM99, their Fig. 14). The first mechanism is strongly local as enhanced cloudiness in the daytime would lead to a reduction of incoming solar radiation contributing to a lowering of sea surface temperatures to a point where they cannot support convection. The second mechanism is strongly non-local as the tradewinds intensify from the Caribbean to the Pacific across Central America. The third mechanism is tied to the enhanced tradewinds, but may also be a response to localized changes in circulation brought about by land-sea contrasts in convection over the diurnal cycle. Recent studies have shown that rainfall peaks in the early evening over Mexico, whereas the opposite is true for the far-eastern Pacific (Negri et al. 1994, Mapes et al. 2003).

This study explores the proposed localized forcing mechanisms by quantifying changes in the diurnal cycle of rainfall and winds over the summer season. First, it will be determined whether there is a statistically significant relationship between the MSD signal and the diurnal cycle of precipitation over land and ocean during the summer season. Once that has been established, maps of the diurnal cycle of precipitation and winds during the course of the summer will be examined to answer 2 specific questions regarding the domain of the MSD: (1) Does the onset of the MSD coincide with a diminishing of the land-sea contrast in the diurnal cycle of precipitation, and could this change be large enough to have an impact on the local winds and wind stirring of the coastal Pacific waters? (2) Is daytime cloud cover/precipitation enhanced prior to the MSD as compared to during the MSD, thus affecting the amount of incoming solar radiation at the ocean surface? In 'Data and methods' (Section 2) recent data sets and simple methods will be introduced to help answer these questions. Results and conclusions will be discussed in Sections 3 and 4 respectively.

\section{DATA AND METHODS}

Until recently, there has not been an observational rainfall data set with a long enough record to make a climatology of diurnal cycle over both land and oceans. Todd \& Washington (1999) devised a simple method to estimate tropical precipitation from the International Satellite Cloud Climatology Program (ISCCP) data. The technique reconstructs the Geostationary Operational Environmental Satellite (GOES) Precipitation Index (GPI; Arkin \& Meisner 1987) every $3 \mathrm{~h}$ from July 1983 to September 2001 at a $2.5^{\circ}$ latitude/longitude grid. Todd \& Washington (1999) also sum the data into a daily product.

National Center for Environmental Prediction (NCEP) reanalysis (Kalnay et al. 1996) u- and v-com- ponents of the surface wind were obtained every $6 \mathrm{~h}$ from the Climate Diagnostics Center (CDC) (available at: www.cdc.noaa.gov/cdc/data.ncep.reanalysis.html). These products are also at a $2.5^{\circ}$ resolution but with a slightly different gridding scheme. Data were collected to match the rainfall record.

Only the boreal summer season was considered for this study. The length of record includes both strong El Niños and La Niñas, so the effects of these lowfrequency climate variations (Curtis 2002) should be minimized. A simple objective method (Curtis 2002) was used for quantifying the bimodal nature of May to October precipitation. First, the variance explained by the second order harmonic of the May to October climatology of daily precipitation was computed globally, to determine if the Todd \& Washington (1999) data set captures the MSD signature. The time series of precipitation are actually composed of the first order harmonic, second order harmonic, and other higher frequency oscillations. The second order harmonic yields a sinusoidal wave with 2 peaks and 2 troughs. Only in the special case where 1 of the troughs is very close to the beginning (early May) or end (late October) of the record does the second order harmonic represent the mid-summer minimum condition. The largest variance explained over the globe is in the MSD region (Fig. 1), reaching values in excess of $45 \%$, consistent with Curtis (2002). A more detailed inspec-

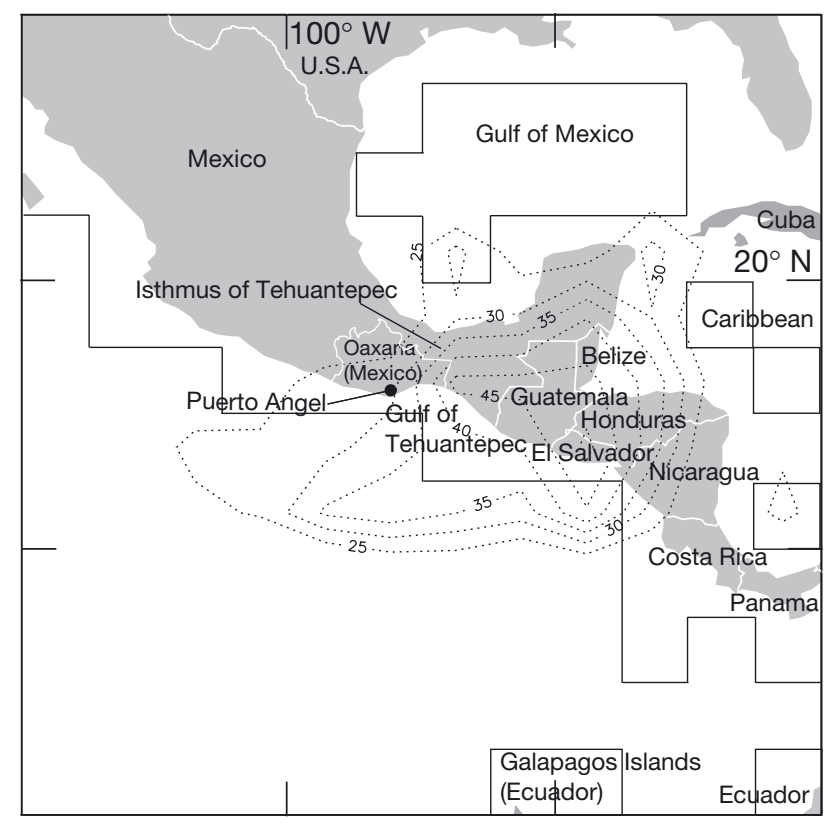

Fig. 1. Mid-summer drought region. Dashed lines denote variance explained $(\%)$ by the second-order harmonic for climatological (1984 to 2000) May to October precipitation. Solid lines denote boundary between ocean and land grid blocks 
tion shows the largest values over land in far-southern Mexico, Guatemala, and El Salvador. The precise location of maximum MSD is likely on the Pacific coast of Central America, as observed by gauge data (MAM99, their Fig. 9).

First, it had to be determined whether the MSD climate signal is associated with a change in the diurnal cycle of precipitation. To test this, the season was divided into 30-d segments: June 1 to 30, July 17 to August 15, and September 1 to 30. For each segment, spatial correlations were computed between the variance explained by the MSD (Fig. 1) and climatological precipitation maps at 8 times of the day over ocean and land separately (see boundary in Fig. 1). 'Ocean' is defined as all $2.5^{\circ}$ grid blocks completely covered $(100 \%)$ by water surface, so 'land' includes coastal areas and small islands. Both climatological fields, MSD and hourly precipitation, have a high level of spatial autocorrelation. Thus, to determine the level of bivariate association, Haining (2003) suggests either a distributional significance test with a reduced number of degrees of freedom based on a spatial detrending (Clifford \& Richardson 1985) or a generalized Monte Carlo approach (Livezey \& Chen 1983, Besag \& Clifford 1989). Here a Monte Carlo approach is employed, as the longer time-scale signal, MSD, was correlated with 1000 randomized repetitions of the shorter timescale response, precipitation. Then the rank of the actual correlation among the 1000 runs was used to determine the level of significance.

\section{RESULTS}

Some of the strongest spatial correlations between the variance explained by MSD and hourly precipitation occur in June over land between 18:00 and 03:00 h LST (Table 1), where LST is for most of the domain in Fig. 1 and is equivalent to UTC-06. At the same time, there is little correlation between ocean blocks and the MSD (Table 1). Conversely, June correlations are strongest over ocean between 06:00 and 12:00 h LST
(Table 1). This suggests a positive relationship between the strength of the MSD and the range of precipitation over the diurnal cycle for both land and ocean. In fact, the correlation of the difference of the maximum minus the minimum precipitation rate with the MSD is 0.53 and 0.54 for land and ocean blocks respectively. In July-August correlations between rain rate and the MSD are low, with only ocean blocks in the mid- to late-morning hours reaching significance (Table 1). In September, correlations between rainfall and MSD strengthen, especially over the oceans where every point in the diurnal cycle is significant (Table 1). This is likely due to the fact that during this month the Intertropical Convergence Zone (ITCZ) and associated heavy rainfall is positioned over some of the largest explained variances in Fig. 1.

This broad examination of the relationship between the diurnal cycle of rainfall and MSD for Mexico, Central America, and surrounding oceans is refined by exploring maps of precipitation for local nighttime (18:00 to 03:00 h LST) and daytime (06:00 to 15:00 h LST) hours. Condensing the data into these averages seems appropriate considering the results of Table 1. Aspects of the diurnal cycle for June are shown in Fig. 2. During night (Fig. 2a) precipitation is a maximum (>18 $\mathrm{mm} \mathrm{d}^{-1}$ ) over Guatemala, at the center of the strongest MSD signal (Fig. 1). Precipitation decreases up the coast of Mexico and along the west coast of Nicaragua. Southward from Guatemala precipitation reaches a minimum of less than $8 \mathrm{~mm} \mathrm{~d}^{-1}$, before increasing into the vicinity of the ITCZ. During day (Fig. 2b) precipitation is greatly reduced for countries north of Nicaragua, and the oceanic rainfall minimum is substantially weakened. Fig. 2c, which represents the strength of the diurnal cycle, shows the statistically significant night minus day differences. The diurnal cycle over land is driven by nighttime rainfall, and thus is most pronounced where the MSD is strongest (Fig. 1). The diurnal cycle is opposite but not as strong over the coastal Pacific. Differences less than $-3 \mathrm{~mm}$ $\mathrm{d}^{-1}$ are found from $90^{\circ} \mathrm{W}$ westward, again mirroring the contours of explained variance in Fig. 1.

Table 1. Spatial correlations between climatological summertime precipitation rates at 8 times during the diurnal cycle (LST or UTC-06) and the strength of the mid-summer drought (MSD; see Fig. 1). Data are divided into subseasons (June, July to August and September) and land versus ocean. ${ }^{*}$ Significant at the $1 \%$ level according to Monte Carlo experiment

\begin{tabular}{|c|c|c|c|c|c|c|c|c|}
\hline Date/surface & 18:00 & $21: 00$ & 00:00 & 03:00 & 06:00 & 09:00 & $12: 00$ & $15: 00$ \\
\hline Jun/land & $0.52^{*}$ & $0.56^{*}$ & $0.64^{*}$ & $0.60^{*}$ & $0.39^{*}$ & 0.18 & 0.12 & $0.34^{*}$ \\
\hline Jun/ocean & 0.16 & 0.10 & 0.12 & 0.24 & $0.33^{*}$ & $0.38^{*}$ & $0.35^{*}$ & 0.26 \\
\hline Jul 17 to Aug 15/land & 0.15 & 0.13 & 0.23 & 0.24 & 0.08 & -0.04 & -0.05 & 0.22 \\
\hline Jul 17 to Aug 15/ocean & 0.12 & 0.09 & 0.14 & 0.26 & $0.34^{*}$ & $0.35^{*}$ & 0.29 & 0.11 \\
\hline Sep/land & $0.50^{*}$ & $0.54^{*}$ & $0.60^{*}$ & $0.52^{*}$ & 0.27 & 0.07 & 0.03 & $0.35^{*}$ \\
\hline Sep/ocean & $0.33^{*}$ & $0.30^{*}$ & $0.42^{*}$ & $0.54^{*}$ & $0.59^{*}$ & $0.57^{*}$ & $0.52^{*}$ & $0.44^{*}$ \\
\hline
\end{tabular}




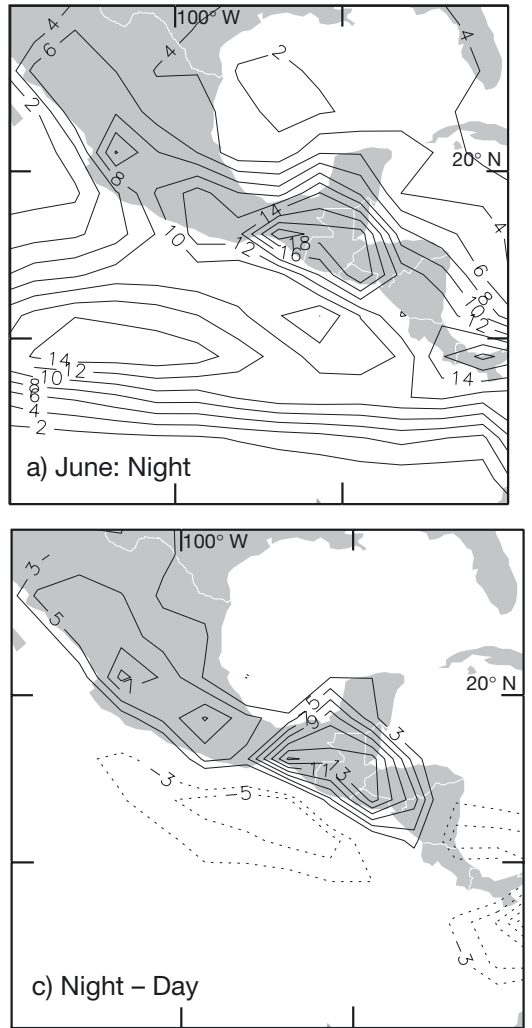

Fig. 2. Precipitation rates $\left(\mathrm{mm} \mathrm{d}^{-1}\right)$ averaged for June at (a) night: 18:00, 21:00, 00:00, and 03:00 h LST, and (b) day: 06:00, 09:00, 12:00, and 15:00 h LST. (c) Difference between (a) and (b) (night - day). Contours are drawn only where differences are significant at the $5 \%$ level, according to $t$-test
Costa Rica, while values less than $8 \mathrm{~mm}$ $\mathrm{d}^{-1}$ bulge northward at $90^{\circ} \mathrm{W}$. During day (Fig. 4b) precipitation is weak over land areas north of Nicaragua, with the exception of Oaxaca, Mexico where precipitation rates in excess of $6 \mathrm{~mm} \mathrm{~d}^{-1}$ bridge the Pacific and Gulf of Mexico. Precipitation is intense just to the south over the Pacific Ocean, where values exceed $18 \mathrm{~mm} \mathrm{~d}^{-1}$. The magnitude of the diurnal cycle (Fig. 4c) has a similar pattern as in July-August (Fig. 3c) but varies in intensity. The diurnal cycle is greater over Guatemala, less over northwest Mexico, and about the same over central Mexico. The oceanic diurnal cycle is most intense compared to the other 2 subseasons, with a large area of less than $-7 \mathrm{~mm} \mathrm{~d}^{-1}$ off the coast of southern Mexico.

Statistically significant differences in both daytime and nighttime rainfall over the course of the summer are shown in Fig. 5. Fig. 5a is the difference between June and July-August daytime rainfall (Fig. 2a-Fig. 3a). Precipitation
The diurnal cycle for July-August is shown in Fig. 3. During night (Fig. 3a) precipitation rates are fairly uniform for the west coast of Mexico and Central America, with values ranging from 10 to $14 \mathrm{~mm} \mathrm{~d}^{-1}$. The minimum in the far eastern Pacific reaches $6 \mathrm{~mm} \mathrm{~d}^{-1}$, while rates in excess of $12 \mathrm{~mm} \mathrm{~d}^{-1}$ are confined west of $105^{\circ} \mathrm{W}$. During day (Fig. 3b), rainfall is again reduced for countries north of Nicaragua, and enhanced off shore. The intensity of the diurnal cycle (Fig. 3c) has a similar pattern as in June (Fig. 2c). However, the strength is less over Guatemala, greater over northwest Mexico, and about the same over central Mexico. The largest differences over the ocean have shifted westward from June to July-August.

The diurnal cycle for September is shown in Fig. 4. During night (Fig. 4a) rainfall is a maximum in southern Mexico and El Salvador $\left(>18 \mathrm{~mm} \mathrm{~d}^{-1}\right)$. Precipitation rates in excess of $10 \mathrm{~mm} \mathrm{~d}^{-1}$ arch northward from $10^{\circ} \mathrm{N}$ and $110^{\circ} \mathrm{W}$, and follow the coast from Mexico to
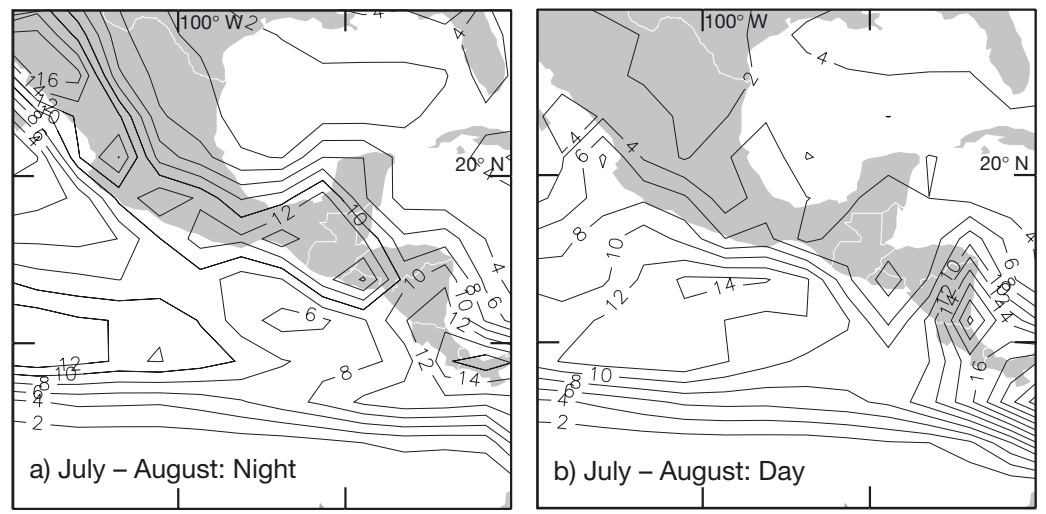

Fig. 3. Precipitation rates $\left(\mathrm{mm} \mathrm{d}^{-1}\right)$ averaged for July 17 to August 15 at (a) night: 18:00, 21:00, 00:00, and 03:00 h LST, and (b) day: 06:00, 09:00, 12:00, and 15:00 h LST. (c) Difference between (a) and (b) (night - day). Contours are drawn only where differences are significant at the $5 \%$ level, according to $t$-test

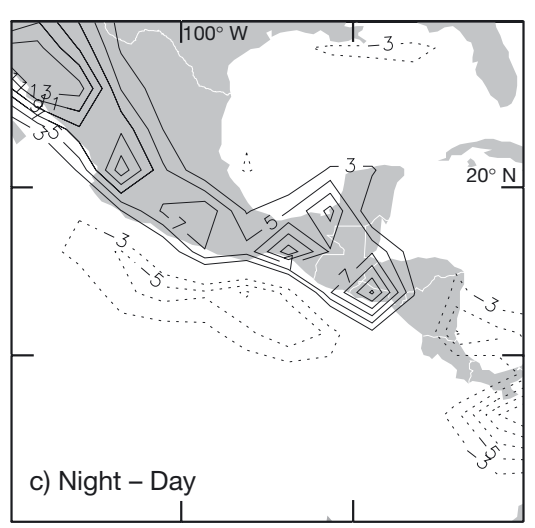




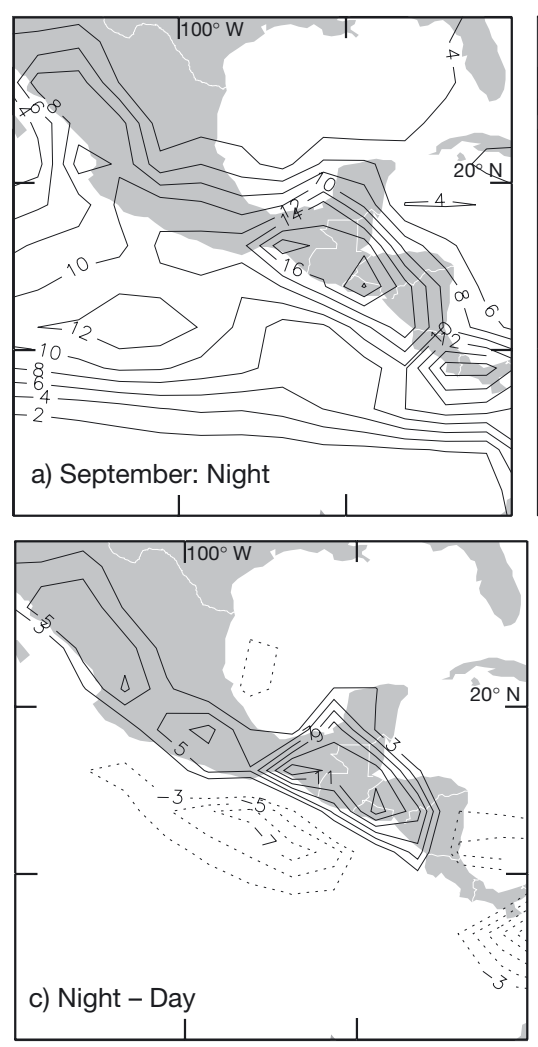

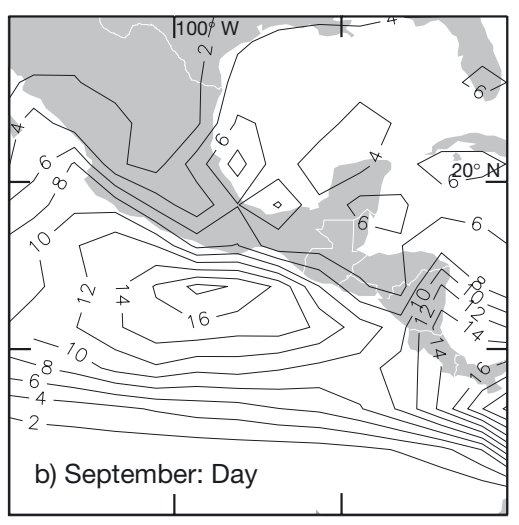

Fig. 4. Precipitation rates $\left(\mathrm{mm} \mathrm{d}^{-1}\right)$ averaged for September at (a) night: 18:00, 21:00, 00:00, and 03:00 h LST, and (b) day: 06:00, 09:00, 12:00, and 15:00 h LST. (c) Difference between (a) and (b) (night - day). Contours are drawn only where differences are significant at the $5 \%$ level, according to $t$-test daytime rainfall (Fig. 4a - Fig. 3a). The pattern is similar to Fig. 5a. However, the differences are weaker in general. For daylight hours, the September minus July-August precipitation map (Fig. $5 d=$ Fig. 4 b - Fig. 3b) shows a band of differences in excess of $3 \mathrm{~mm} \mathrm{~d}^{-1}$ over the coastal Pacific, otherwise it is similar to the June minus July-August map (Fig. 5b) in the region of interest.

Finally, diurnally resolved reanalysis surface winds are used to investigate whether the changes in nighttime and daytime precipitation over the course of the summer are accompanied by dynamically consistent changes in the wind field. In the same manner as the precipitation data, June nighttime, daytime, and night minus day difference fields are shown in Fig. 6a, b, and c respectively. Strong tradewinds are shown on the Gulf and Caribbean side of Mexico and Central America. The ITCZ is identified in the Pacific by the curvature of winds from southerly to westerly. The daytime (Fig. 6a) and is $5 \mathrm{~mm} \mathrm{~d}^{-1}$ greater in June than JulyAugust over Guatemala and $3 \mathrm{~mm} \mathrm{~d}^{-1}$ greater to the south over the Pacific. Northward along the west coast of Mexico, the precipitation differences become strongly negative in the vicinity of the North American Monsoon. Precipitation changes little between June and July-August over land during the day (Fig. 5b = Fig. 2b-Fig. 3b). Over the Pacific Ocean precipitation differences exceed $5 \mathrm{~mm} \mathrm{~d}^{-1}$ to the east of $100^{\circ} \mathrm{W}$, and are negative off the coast of central Mexico. Fig. 5c is the difference between September and July-August

Fig. 5. $(\mathrm{a}, \mathrm{b})$ Precipitation rates averaged for June minus precipitation rates averaged from July 17 to August $15\left(\mathrm{~mm} \mathrm{~d}^{-1}\right)$ for (a) night: 18:00, 21:00, 00:00, and 03:00 h LST, and (b) day: 06:00, 09:00, 12:00, and 15:00 h LST. $(c, d)$ Precipitation rates averaged for September minus precipitation rates averaged from July 17 to August $15\left(\mathrm{~mm} \mathrm{~d}^{-1}\right)$ for (c) night, and (d) day. Contours are drawn only where differences are significant at the $5 \%$ level, according to $t$-test

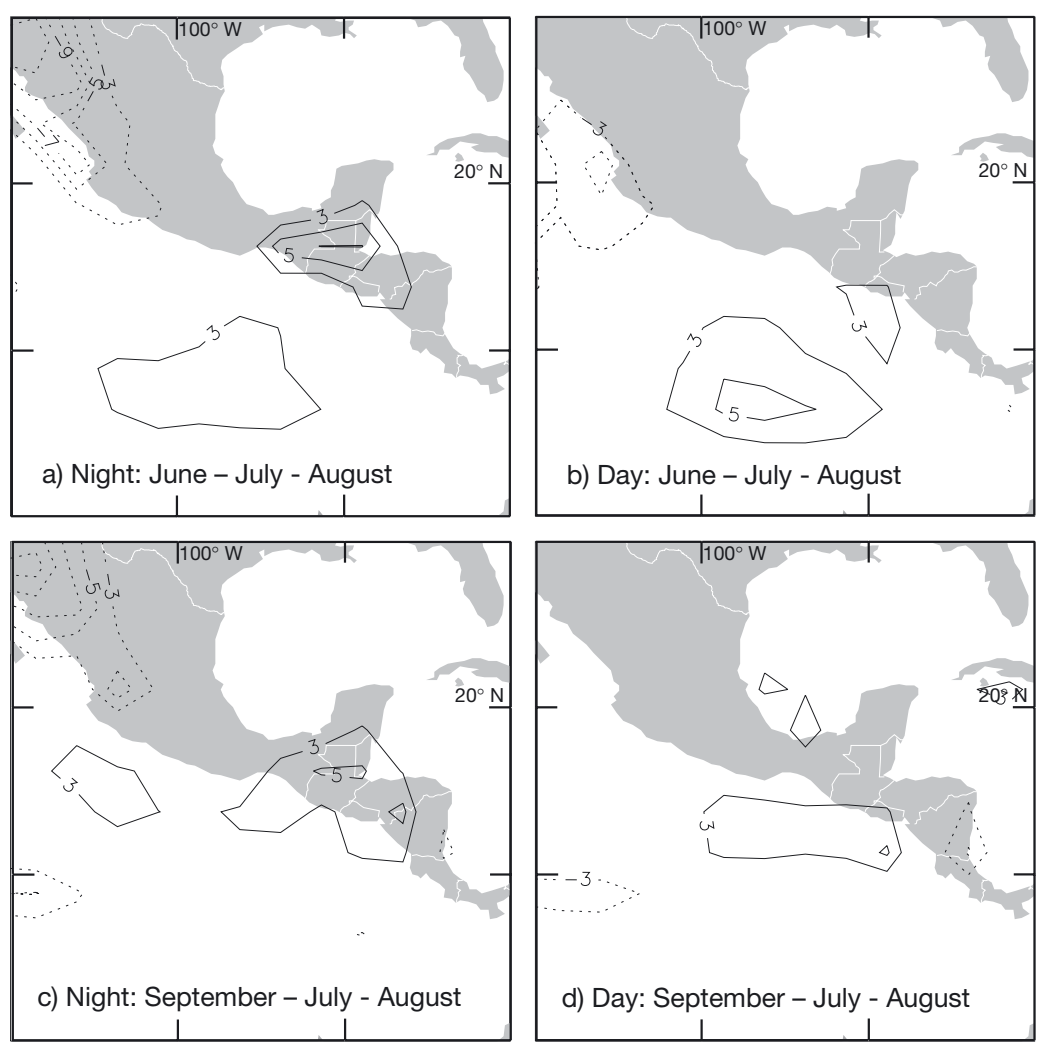



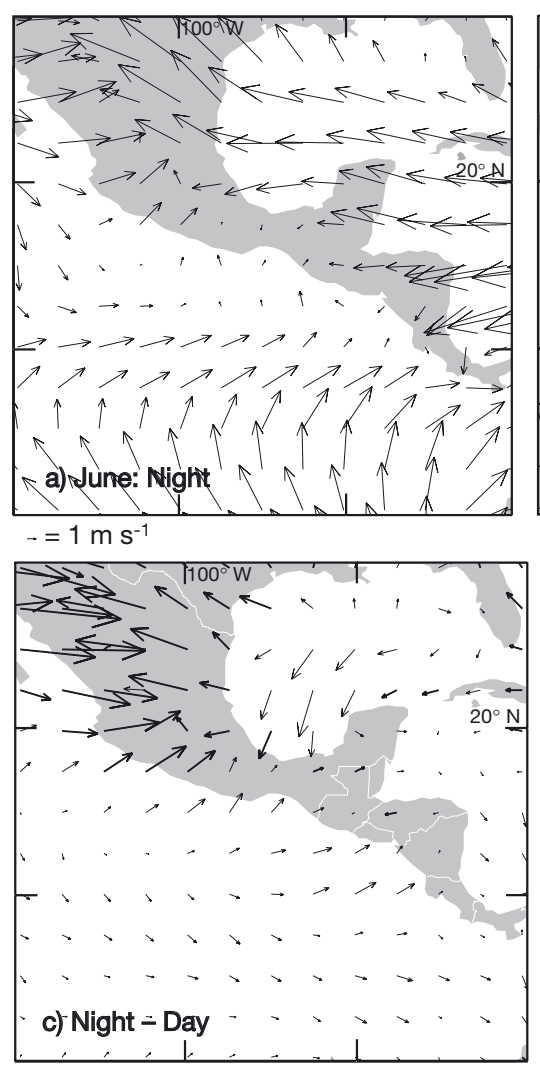

$\rightarrow=1 \mathrm{~m} \mathrm{~s}^{-1}$

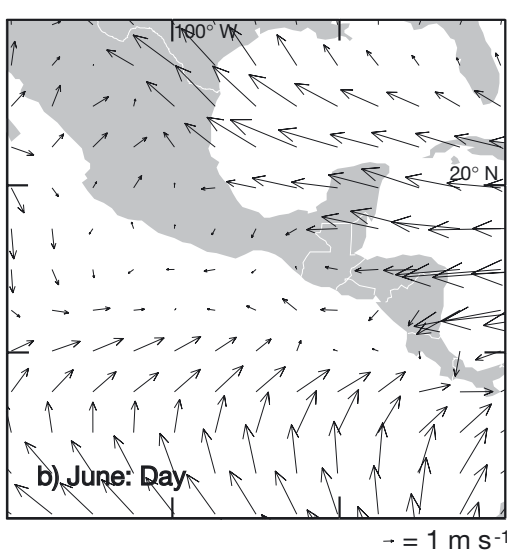

Fig. 6. Vectors of surface wind (m $\mathrm{s}^{-1}$ ) averaged for June at (a) night: 18:00 and 0:00 h LST, and (b) day: 06:00 and 12:00 h LST. (c) Wind difference between (a) and (b) (night - day). Differences in wind speed at the $5 \%$ significance level, according to $t$-test, are drawn in bold. Keys denote the relation between vector length and wind speed cantly faster during night on the Gulf of Mexico side of the Isthmus of Tehuantepec and faster during day on the Pacific side (Fig. $7 \mathrm{c}$ ). It is interesting to note that there no longer exists a reversal of wind direction in the vicinity of the Gulf of Tehuantepec from night (Fig. 7a) to day (Fig. 7b), as was observed in June (Fig. 6a,b). Rather, winds are consistently northerly to northeasterly, agreeing with a climatology of monthly wind observations on the southern coast of the Isthmus of Tehuantepec (Romero-Centeno et al. 2003).

In September the Pacific tradewinds accompanying the ITCZ move furthest north. Winds are directed more towards land for night versus day, but wind speeds have weakened from JulyAugust. The differences in daytime and nighttime wind between June and July-August and September and July to August were taken (not shown), and found to be consistent with MAM99, their Fig. 8. The onset of the MSD is accompanied by a strengthening of the tradewinds over Central America, and nighttime (Fig. 6b) large-scale circulations are similar in direction and magnitude. However, the weak winds from the Gulf of Tehuantepec westward are directed northward toward the convection over land at night (Fig. 6a) and southward toward the oceanic convection during the day (Fig. 6b). The night minus day difference (Fig. 6c) further reveals that a component of the largescale flow over the eastern Pacific and Gulf of Mexico is dynamically consistent with the diurnal cycle of rainfall. Significant increases in wind speed from day to night are confined to central to northern Mexico.

The July-August period is shown in Fig. 7. In both the day (Fig. 7a) and night (Fig. 7b) hours, the tradewinds extend from the Caribbean across Central America and into the Pacific. Even though the land-sea contrast in diurnal cycle is weaker for July-August compared to June, winds are still directed more towards land at night versus day (Fig. $7 \mathrm{c}$ ). The tradewinds are signifi-
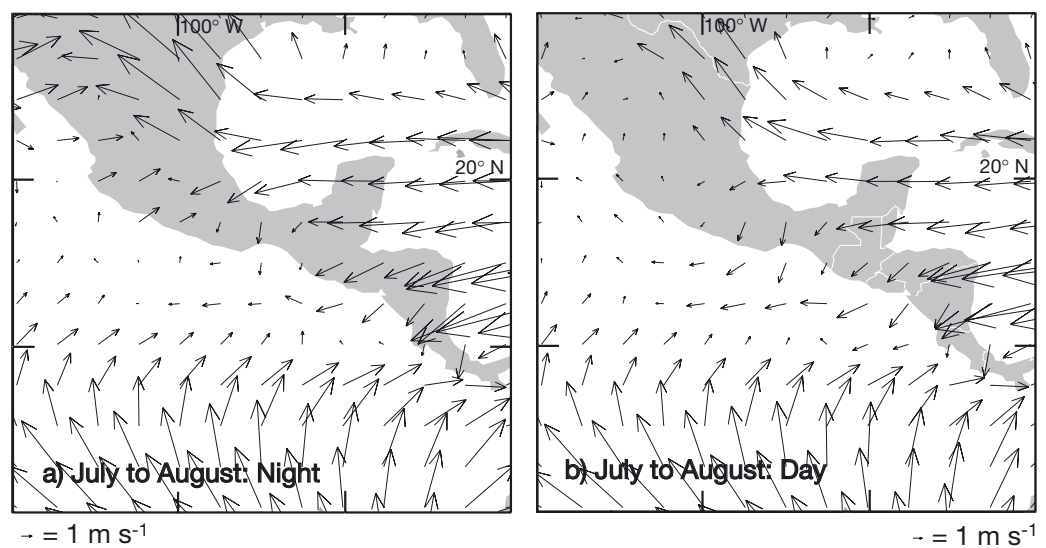

Fig. 7. Vectors of surface wind $(\mathrm{m}$ $\mathrm{s}^{-1}$ ) averaged for July 17 to August 15 at (a) night: 18:00 and 0:00 h LST, and (b) day: 06:00 and 12:00 h LST. (c) Wind difference between (a) and (b) (night-day). Differences in wind speed at the $5 \%$ significance level, according to $t$-test, are drawn in bold. Keys denote the relation between vector length and wind speed

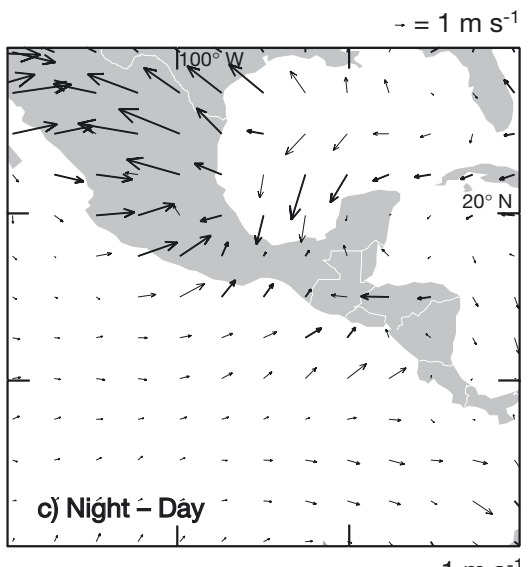




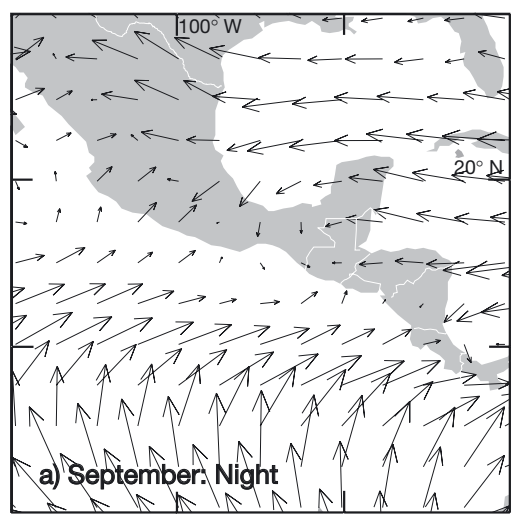

$\rightarrow=1 \mathrm{~m} \mathrm{~s}^{-1}$

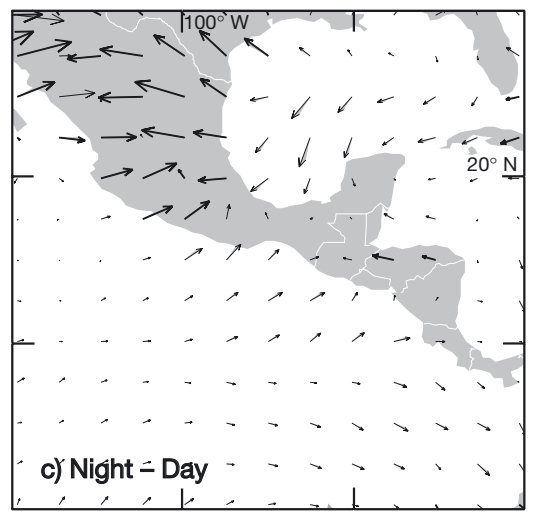

$\rightarrow=1 \mathrm{~m} \mathrm{~s}^{-1}$

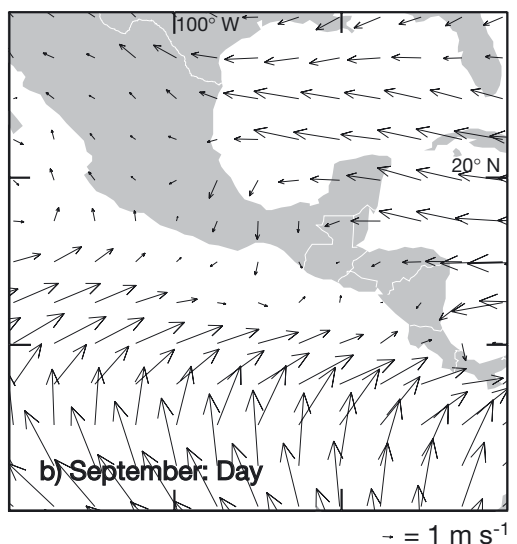

Fig. 8. Vectors of surface wind $\left(\mathrm{m} \mathrm{s}^{-1}\right)$ averaged for September at (a) night: 18:00 and 0:00 h LST, and (b) day: 06:00 and 12:00 h LST. (c) Wind difference between (a) and (b) (night - day). Differences in wind speed at the $5 \%$ significance level, according to $t$-test, are drawn in bold. Keys denote the relation between vector length and wind speed nal cycle, to a point where there is essentially no relationship between the diurnal cycle of rainfall and the strength of the MSD in July-August.

Precipitation maps showed the largest land-sea contrast in the diurnal cycle from the Isthmus of Tehuantepec to the eastern Pacific for June and September. Reanalysis data was then examined to test whether the land-sea contrast in the diurnal cycle of precipitation is consistent with the surface winds. Prior to the MSD, wind flows from the Pacific into the Isthmus of Tehuantepec during the night and from land to sea during the day, but the localized winds are weak and alone are unlikely to cool the sea surface sufficiently to destabilize convection. The overall reduction of rainfall is more likely attributed to changes in the large-scale circulation, namely an anomalous anticyclonic circulation in July-August, which would induce surface divergence in the vicinity of strongest MSD signal. Finally, the end of the MSD in September is characterized by a northward shift in the ITCZ as evidenced by the precipitation and surface wind field.

an anomalous surface anticyclonic circulation centered off the coast of central Mexico. The demise of the MSD is accompanied by a weakening of the tradewinds, and an anomalous surface cyclonic circulation centered off the coast of Mexico.

\section{DISCUSSION AND SUMMARY}

This study examined the diurnal cycle of rainfall and winds in the vicinity of southern Mexico and Central America, to shed light on the role of localized forcing mechanisms in the evolution of MSD. In regions where the MSD explains a high percentage of the summertime variance, the land-sea contrast in the diurnal cycle is pronounced in June, meaning rainfall is abundant over land at night and over the ocean in the daytime. In July-August precipitation over land decreases by about $25 \%$ during the night and is nearly unchanged during the day. Cloudiness and precipitation over ocean decrease from June to July-August during the day over the ocean, allowing for enhanced solar radiation and a warming of the surface waters. These changes diminish the land-sea contrast in the diur-
Table 2. Averaged precipitation rates for Puerto Angel, Mexico. Data are divided by time of day and subseason

\begin{tabular}{|lccc|}
\hline Precipitation rate $\left(\mathrm{mm} \mathrm{d}^{-1}\right)$ & Jun 1-30 & Jul 17-Aug 15 & Sep 1-30 \\
\hline Night (18:00-03:00 h LST) & 8.01 & 6.50 & 11.78 \\
Day (06:00-15:00 h LST) & 4.44 & 1.90 & 2.68 \\
\hline
\end{tabular}


daytime and nighttime precipitation values are reduced during the MSD, consistent with the findings of this paper. Preliminary work with diurnally resolved wind observations at Salina Cruz (16 $10^{\circ} 15^{\prime \prime} \mathrm{N}$, $95^{\circ} 10^{\prime} 45^{\prime \prime} \mathrm{W}$ ) show a reduction in observations of southerly wind at 18:00 h LST from $50 \%$ in June to less than $30 \%$ in July-August (R. Romero-Centeno, Centro de Ciencias de la Atmosfera, Mexico City, pers. comm.), consistent with the reversal of the nighttime wind vector in the Gulf of Tehuantepec from June to July-August (Figs. 6a \& 7a).

In summary, several new findings about the MSD were revealed in this study given the limited amount of data, which help address the original 2 questions posed in the 'Introduction'. Over land the intensity of the diurnal cycle of precipitation is consistent with the seasonal march of rainfall. Prior to the MSD the land-sea contrast in daytime and nighttime precipitation is strong in the vicinity of the Gulf of Tehuantepec, and only then do the local winds reverse direction consistent with this contrast, but the wind speeds do not change significantly and thus do not appear to play a role in wind stirring and the cooling of the sea surface. Daytime precipitation is greater prior to rather than during the MSD over the Pacific, consistent with proposed local solar forcing of sea surface temperatures in the evolution of the MSD. Finally, the onset of the MSD coincides with a reduction of the land-sea contrast in the diurnal cycle of precipitation. These relationships do not hold only short distances away from the areas most affected by the MSD.

Acknowledgements: The author would like to thank 3 anonymous reviewers for their comments, which greatly improved an earlier version of this manuscript. The author would also like to thank the Servicio Meteorológico Nacional (Mexico) for providing the 3 hourly precipitation data for Puerto Angel, Dr. Rebecca Torres for translating documents from Spanish to English, and Dr. Ronald Mitchelson and Mr. Rosario RomeroCenteno for their helpful discussions.

Editorial responsibility: Robert Davis, Charlottesville, Virginia, USA

\section{LITERATURE CITED}

Arbingast SA (1975) Atlas of Mexico. University of Texas at Austin, TX

Arkin PA, Meisner BN (1987) The relationship between largescale convective rainfall and cold cloud over the Western Hemisphere during 1982-84. Mon Weather Rev 115: 51-74

Besag J, Clifford P (1989) Generalized Monte Carlo significance tests. Biometrika 76:633-642

Clifford P, Richardson S (1985) Testing the association between 2 spatial processes. Statistics and Decisions, Suppl. 2:155-160

Curtis S (2002) Interannual variability of the bimodal distribution of summertime rainfall over Central America and tropical storm activity in the far-eastern Pacific. Clim Res 22:141-146

Diagram Group (1985) The Atlas of Central America and Caribbean. Macmillan Publishing, New York,

Haining R (2003) Spatial data analysis: theory and practice. Cambridge University Press, New York

Hastenrath S (1967) Rainfall distribution and regime in Central America. Arch Meteor Geophys Bioklimatol 15B: 201-241

Kalnay E, Kanamitsu M, Kistler R, Collins W and 18 others (1996) The NCEP/NCAR 40-Year Reanalysis Project. Bull Am Meteorol Soc 77:437-471

Livezey RE, Chen WY (1983) Statistical field significance and its determination by Monte Carlo techniques. Mon Weather Rev 111:46-59

Magaña V, Amador JA, Medina S (1999) The midsummer drought over Mexico and Central America. J Clim 12:1577-1588

Mapes BE, Warner TT, Xu M, Negri AJ (2003) Diurnal patterns of rainfall in northwestern South America. Part I: Observations and context. Mon Weather Rev 131:799-812

Negri AJ, Adler RF, Nelkin EJ, Huffman G (1994) Regional rainfall climatologies derived from Special Sensor Microwave Imager (SSM/I) data. Bull Am Meteorol Soc 75:1165-1182

Romero-Centeno R, Zavala-Hidalgo J, Gallegos A, O'Brien JJ (2003) Isthmus of Tehuantepec wind climatology and ENSO signal. J Clim 16:2628-2639

Todd M, Washington R (1999) A simple method to retrieve 3hourly estimates of global tropical and subtropical precipitation from International Satellite Cloud Climatology Program (ISCCP) D1 data. J Atmos Oceanic Tech 16: 146-155

Submitted: November 18, 2003; Accepted: June 21, 2004

Proofs received from author(s): July 8, 2004 